\title{
Effects of synchronization treatments on ovarian follicular dynamics, corpus luteum growth, and circulating steroid hormone concentrations in lactating dairy cows
}

\author{
M. M. Herlihy, ${ }^{*} †$ M. A. Crowe, $†$ M. G. Diskin, $\neq$ and S. T. Butler ${ }^{* 1}$ \\ *Teagasc, Animal and Grassland Research and Innovation Centre, Moorepark, Fermoy, Co. Cork, Ireland \\ †School of Agriculture, Food Science and Veterinary Medicine, University College Dublin, Belfield, Dublin 4, Ireland \\ ¥Teagasc, Animal and Grassland Research and Innovation Centre, Mellows Campus, Athenry, Co. Galway, Ireland
}

\begin{abstract}
Lactating dairy cows $(\mathrm{n}=57) \geq 45 \mathrm{~d}$ postpartum at first service were enrolled in a randomized complete block design study to evaluate treatments to synchronize estrus and ovulation. At $10 \mathrm{~d}$ before artificial insemination (AI), animals were randomly assigned to 1 of 3 treatments: (1) d $-10 \mathrm{GnRH}$ (GnRH1; 10 $\mu \mathrm{g}$ of buserelin, i.m.) and controlled internal drug release insert [CIDR, $1.38 \mathrm{~g}$ of progesterone (P4)]; $\mathrm{d}-3$ $\mathrm{PGF}_{2 \alpha}$ (PGF; $25 \mathrm{mg}$ of dinoprost, i.m.); d -2 CIDR out; and AI at observed estrus (CIDR_OBS); (2) same as CIDR_OBS, but GnRH (GnRH2) $36 \mathrm{~h}$ after CIDR out and timed AI (TAI) $18 \mathrm{~h}$ later (CIDR_TAI); or (3) same as CIDR_TAI, but no CIDR (Ovsynch). Transrectal ultrasound was used to assess follicle size before ovulation and on d 4, 8, and 15 after the presumptive day of estrus (d 0) to measure the corpus luteum (CL). Blood samples were collected to determine concentrations of estradiol (E2; d $-10,-9,-3,-2,-1$, and 0 ) and $\mathrm{P} 4(\mathrm{~d}-10,-9,-2,-1,0,1,4,6,8,11$, and 15$)$. No treatment differences were observed in either circulating concentrations of $\mathrm{P} 4$ or the ovulatory response to GnRH1 at the onset of synchronization treatments. Circulating concentrations of $\mathrm{P} 4$ were greater for CIDR OBS and CIDR_TAI compared with Ovsynch at $24 \mathrm{~h}$ after CIDR insertion (5.34 and 4.98 vs. $1.75 \mathrm{ng} / \mathrm{mL}$ ) and immediately before CIDR removal (1.65 and 1.48 vs. $0.40 \mathrm{ng} / \mathrm{mL}$ ). Peak circulating concentrations of E2 were greater for CIDR_OBS compared with Ovsynch (3.85 vs. $2.39 \mathrm{pg} / \mathrm{mL})$, but CIDR_TAI $(2.82 \mathrm{pg} / \mathrm{mL})$ did not differ from either CIDR_OBS or Ovsynch. The interval from PGF injection to peak circulating E2 did not differ between CIDR_TAI and Ovsynch (52.1 vs. 49.8 h). Both CIDR_TAI and Ovsynch, however, had shorter intervals from PGF injection to peak circulating E2 concentrations compared with CIDR_OBS
\end{abstract}

Received July 28, 2011.

Accepted October 7, 2011.

${ }^{1}$ Corresponding author: Stephen.Butler@teagasc.ie
$(67.8 \mathrm{~h})$. The diameter of the dominant follicle before ovulation was greater for CIDR_OBS compared with Ovsynch (18.5 vs. $16.0 \mathrm{~mm}$ ) but CIDR_TAI (17.1 $\mathrm{mm}$ ) did not differ from either of the other treatments. The mean interval from PGF to ovulation was longer for CIDR_OBS $(100.0 \mathrm{~h})$ compared with CIDR_TAI and Ovsynch (84.4 and $83.2 \mathrm{~h}$, respectively). Use of CIDR_OBS resulted in increased preovulatory follicle size and greater circulating concentrations of E2 due to a longer period of preovulatory follicle growth. Progesterone supplementation during synchronization and GnRH on the day before TAI affected ovulatory follicle size, and periovulatory circulating concentrations of $\mathrm{P} 4$ and E2. No differences, however, in postovulatory P4 or luteal volume profiles were observed.

Key words: estrous synchronization, Ovsynch, progesterone, dairy cow

\section{INTRODUCTION}

Reproductive management of lactating dairy cows is frequently compromised due to poor expression of estrus. Timed AI (TAI) programs can be implemented, allowing TAI before an induced ovulation, without requirement for detection of estrus (Thatcher et al., 2010). Treatments to synchronize estrus and ovulation based on GnRH and $\mathrm{PGF}_{2 \alpha}$ (PGF) [with or without progesterone (P4)] maximize the proportion of cows inseminated following the planned start of mating. Satisfactory conception rates are achieved when implemented in commercial dairy herds in seasonal-calving, pasture-based milk production systems (Herlihy et al., 2011).

The Ovsynch treatment synchronizes follicle maturation coincident with regression of the corpus luteum (CL) before GnRH-induced ovulation and TAI. This treatment includes an injection of $\mathrm{GnRH} 7 \mathrm{~d}$ before (GnRH1) and $56 \mathrm{~h}$ after (GnRH2) an injection of PGF (Brusveen et al., 2008). Ovulation occurs within an 8-h interval, 24 to $32 \mathrm{~h}$ after GnRH2 injection (Pursley et al., 1995), facilitating TAI $16 \mathrm{~h}$ after GnRH2 
injection (Pursley et al., 1998). Progesterone is an important regulator of the frequency of pulsatile secretion of LH, and hence plays an important regulatory role in preovulatory follicle development. Lesser concentrations of $\mathrm{P} 4$ in the cycle preceding ovulation may increase the risk of inferior oocyte quality before ovulation and poor embryo quality after fertilization (Ahmad et al., 1995; Revah and Butler, 1996). An ovulatory response to GnRH1 eliminates the risk of a persistent dominant follicle at the time of GnRH2 injection, and ensures the presence of a responsive CL at the time of PGF injection. Administration of $\mathrm{GnRH}$ at random stages of the estrous cycle results in ovulation of a dominant follicle in 54 to $90 \%$ of dairy cows (Pursley et al., 1995; Vasconcelos et al., 1999; Bello et al., 2006), with emergence of a new follicular wave, on average, $2.5 \mathrm{~d}$ later (range 2 to 4 d; Pursley et al., 1995).

Estradiol-17ß (E2) is the endogenous hormone that induces estrous behavior (Allrich, 1994). Estradiol acts on the hypothalamus to induce the release of a surge of GnRH that triggers the preovulatory LH surge (Gazal et al., 1998). Treatment with a bolus injection of a GnRH analog induces an endogenous LH surge that peaks $2 \mathrm{~h}$ after $\mathrm{GnRH}$ injection and induces ovulation of follicles that have acquired ovulatory capacity (Sartori et al., 2001) 22 to $31 \mathrm{~h}$ after the LH surge (Komar et al., 2001). A rapid decrease in blood concentrations of E2 is observed beginning at the peak of the gonadotropin surge (Haughian et al., 2004), reaching a nadir approximately 8 to $10 \mathrm{~h}$ before ovulation (Komar et al., 2001). Synthesis and secretion of P4 by the CL is essential for the establishment and maintenance of pregnancy (Spencer et al., 2004). Systemic concentrations of $\mathrm{P} 4$ in the estrous cycle preceding ovulation and during the early luteal phase of the cycle after AI affect embryo survival (Morris and Diskin, 2008). Greater P4 concentrations during early embryo development increase embryo size (Clemente et al., 2009; Forde et al., 2011).

We have recently reported the effects of TAI treatments (with or without P4) and a conventional controlled internal drug release insert (CIDR)-based estrous synchronization treatment on herd reproductive performance in seasonal calving lactating dairy cows (Herlihy et al., 2011). The objective of this study was to compare the effects of identical treatments on ovarian follicle and CL development and circulating concentrations of steroid hormones in lactating dairy cows. The present study was carried out to identify the underlying mechanisms responsible for the previously documented differences in fertility following use of treatments to synchronize estrus and ovulation in lactating dairy cows.

\section{MATERIALS AND METHODS}

\section{Animals}

This study was conducted at the Animal and Grassland Research and Innovation Centre at Teagasc, Moorepark (County Cork, Ireland) from November 2008 to January 2009. Lactating dairy cows $(\mathrm{n}=64)$ were managed as a single herd, housed indoors in a freestall barn, and allocated $20 \mathrm{~kg}$ of $\mathrm{DM} / \mathrm{cow}$ per day in a TMR consisting of $7.4 \mathrm{~kg}$ of grass silage, $4.0 \mathrm{~kg}$ of maize silage, $0.6 \mathrm{~kg}$ of straw, $7.0 \mathrm{~kg}$ of concentrate, and $1.0 \mathrm{~kg}$ of molasses on a DM basis throughout the experimental period. All experimental procedures involving animals were licensed in accordance with the Cruelty to Animals Act (Ireland 1876) and the European Community Directive 86/609/EC and were sanctioned by the University College Dublin Animal Research Ethics Committee.

\section{Experimental Design, Synchronization Treatments, and Al}

Cows were enrolled in a completely randomized block experimental design, and the experiment was completed in 3 replicates. All cows were $\geq 35$ DIM (mean = 58 ; range 35 to $82 \mathrm{DIM}$ ) at the initiation of synchrony treatments, resulting in synchronized estrus/ovulation at $\geq 45$ DIM $($ mean $=68$; range $=45$ to 92 DIM $)$. Within each replicate, cows were blocked on the basis of parity, cumulative milk yield from wk 2 to 5 of lactation, and BCS 1 wk before treatment initiation and randomly assigned to 1 of the 3 treatments illustrated in Figure 1. One treatment was an estrous synchronization treatment [CIDR_OBS: d -10 GnRH1 $(10 \mu \mathrm{g}$ of buserelin, i.m.) and CIDR (1.38 $\mathrm{g}$ of P4); d -3 PGF (25 mg of dinoprost, i.m.); d -2 CIDR out; and AI at observed estrus], whereas 2 treatments were ovulation synchronization treatments (CIDR_TAI: same as CIDR_OBS, but GnRH2 $36 \mathrm{~h}$ after CIDR out and TAI 18 h later; Ovsynch: same as CIDR_TAI, but no CIDR). All treatments were initiated at a random stage of the estrous cycle. The i.m. GnRH agonist injections contained $10 \mu \mathrm{g}$ of buserelin (Receptal; Intervet Ireland Ltd., Dublin, Ireland). The CIDR device used contained $1.38 \mathrm{~g}$ of $\mathrm{P} 4$ (Pfizer Ireland, Dublin, Ireland). The i.m. $\mathrm{PGF}_{2 \alpha}$ contained $25 \mathrm{mg}$ of dinoprost tromethamine (Lutalyse; Pfizer Ireland). Cows assigned to CIDR_OBS were inseminated using the a.m./p.m. rule (Nebel et al., 1994) following detection of estrus with the aid of tail paint. Detection of estrus was performed 4 times per 24-h period for $20 \mathrm{~min}$ (i.e., 6 -h intervals). All cows on the CIDR_TAI and Ovsynch treatments received TAI $18 \mathrm{~h}$ after GnRH2, which was administered $60 \mathrm{~h}$ 
CIDR_OBS (n=19)

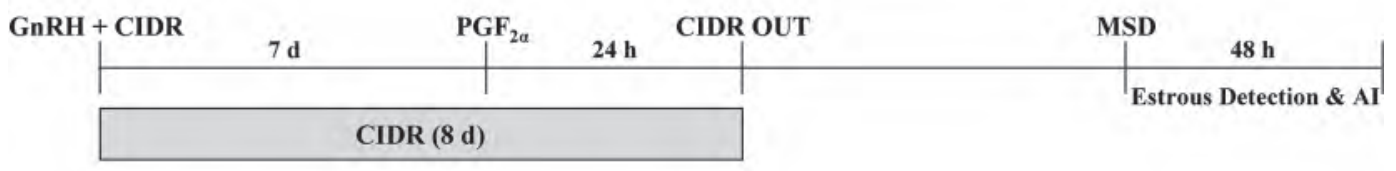

CIDR_TAI (n=18)

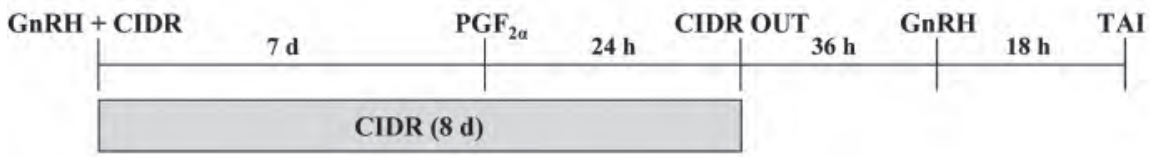

OVSYNCH (n=20)

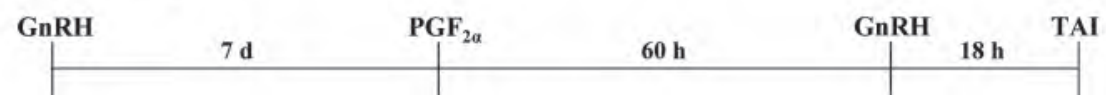

Figure 1. Schematic diagram of treatments to synchronize estrus and ovulation. CIDR $=$ controlled internal drug release; OBS $=$ observed estrus; TAI = timed AI. Insemination commenced on a fixed date, referred to as the mating start date (MSD). Synchronization treatments were initiated at a random stage of the estrous cycle and applied to lactating dairy cows before the first service. CIDR_OBS $=10 \mu \mathrm{g}$ of $\mathrm{GnRH}$ and CIDR insert at d 0,25 mg of $\mathrm{PGF}_{2 \alpha}$ at d 7, CIDR removed at d 8; animals were inseminated by the a.m./p.m. rule following detection of estrus on $\mathrm{d} 10,11$, and 12. CIDR_TAI $=10 \mu \mathrm{g}$ of $\mathrm{GnRH}$ and CIDR insert at d $0,25 \mathrm{mg}$ of $\mathrm{PGF}_{2 \alpha}$ at d 7 , CIDR removed $\mathrm{d} 8,10 \mu \mathrm{g}$ of GnRH $60 \mathrm{~h}$ after $\mathrm{PGF}_{2 \alpha}$ injection or $36 \mathrm{~h}$ after CIDR removal; animals received TAI $18 \mathrm{~h}$ after GnRH2. Ovsynch $=10 \mu \mathrm{g}$ of $\mathrm{GnRH}$ at d $0,25 \mathrm{mg}$ of PGF $\mathrm{F}_{2 \alpha}$ at $\mathrm{d} 7,10 \mu \mathrm{g}$ of $\mathrm{GnRH} 60 \mathrm{~h}$ after $\mathrm{PGF}_{2 \alpha}$ injection; animals received TAI $18 \mathrm{~h}$ after GnRH2.

after PGF injection. All cows were moved to a clean stand-off woodchip pad $3 \mathrm{~d}$ before the presumptive day of estrus until ovulation was confirmed, to enhance expression of estrous behavior. All inseminations were performed by a single experienced technician.

\section{Transrectal Ultrasonography}

Ovarian structures were examined by linear array ultrasonography using a $7.5-\mathrm{MHz}$ transrectal transducer (Aloka SSD-900; Aloka Ltd., Tokyo, Japan). The reproductive tracts of all cows were examined immediately before initiation of synchronization treatments and cows were assigned an ultrasound reproductive tract score describing the volume and echogenicity of fluid contained within the uterus (Mee et al., 2009). Cows that were classified as endometritic were not included in the study. Ultrasound examinations were carried out on all cows according to the following schedule: at treatment initiation to determine follicle and CL diameter; 4 $\mathrm{d}$ after treatment initiation to determine the ovulatory response to GnRH1; 2 d before the presumptive day of estrus to determine dominant follicle diameter; every $8 \mathrm{~h}$ commencing $80 \mathrm{~h}$ after PGF injection $(22 \mathrm{~h}$ after GnRH2 injection for CIDR_TAI and Ovsynch) until $128 \mathrm{~h}$ after PGF injection; and again at $152 \mathrm{~h}$ after PGF injection, until ovulation was confirmed. Ultrasound examinations ceased in animals that failed to ovulate when a new follicular wave had emerged. Ovulation was assumed to have occurred midway between two 8-h observation periods or, in the case of later-ovulating animals, between the two 24-h observation periods. For cows with follicles that ovulated before the first scan on the presumptive day of estrus ( $80 \mathrm{~h}$ after PGF injection), it was assumed that ovulation occurred at $76 \mathrm{~h}$ after PGF injection. Further ultrasound examinations were completed on $\mathrm{d} 4,8$, and 15 after the presumptive day of estrus to determine CL diameter postovulation.

\section{Determination of Luteal Tissue Volume}

An image of the CL was frozen on screen at its maximal area and vertical and horizontal diameters were measured using the integral electronic calipers to determine the mean maximum cross-sectional diameter of the CL. Luteal volume $\left(\mathrm{mm}^{3}\right)$ was calculated as $\mathrm{V}=$ $4 / 3 \times \pi \times \mathrm{r}^{3}$, where the radius ( $\mathrm{r}$ ) was calculated as 0.5 $\times$ mean maximum cross-sectional CL diameter. For CL with a fluid-filled cavity, the volume of the cavity was calculated in an identical manner, and subtracted from the total volume of the CL.

\section{Blood Sampling}

Blood samples were collected on $\mathrm{d}-10,-9,-3,-2$ $(\times 2 ; 12$-h intervals $) ; \mathrm{d}-1$ ( $\times 4$ at 6 -h intervals $) ; \mathrm{d} 0$ 
( $\times 4$ at 6 -h intervals); $\mathrm{d} 1$ ( $\times 1$ for cows with follicles that had ovulated; $\times 3$ at 6 -h intervals for cows with follicles that had not ovulated by $18 \mathrm{~h}$ after animals were bred by TAI); and d 4, $6,8,11$, and 15 relative to the presumptive day of estrus (d 0$)$. For sampling time points that coincided with timing of treatments, blood samples were collected immediately before administration of treatments or CIDR insertion or removal. Blood was collected in lithium heparin Vacutainer tubes (Becton, Dickinson and Co., Plymouth, UK) by puncture of coccygeal vessels, centrifuged at 2,000 $\times g$ for 15 min at $5^{\circ} \mathrm{C}$, and the plasma was harvested and stored at $-20^{\circ} \mathrm{C}$ until later analysis. Concentrations of $\mathrm{E} 2$ were analyzed on $\mathrm{d}-10,-9,-3,-2$ ( $\times 2$ at 12 -h intervals $) ; \mathrm{d}-1$ ( $\times 4$ at 6 -h intervals); d $0(\times 4$ at 6 -h intervals $)$; and $\mathrm{d}$ 1 ( $\times 3$ at 6 -h intervals for cows with follicles that had not ovulated by $18 \mathrm{~h}$ after animals were bred by TAI). Concentrations of $\mathrm{P} 4$ were analyzed on $\mathrm{d}-10,-9,-2$ ( $\times 2$; 12-h intervals), d $-1,0,1,4,6,8,11$, and 15 .

\section{Hormonal Assays}

Concentrations of E2 in plasma were determined by radioimmunoassay following extraction using E2 MAIA kits (Bio-Stat Diagnostic Systems Ltd. Stockport, Cheshire, UK) as described previously (Prendiville et al., 1995). The mean interassay and intra-assay coefficients of variation for high-quality control samples were 1.84 and $6.84 \%$, respectively, with a mean concentration of $3.95 \mathrm{pg} / \mathrm{mL}$. The minimum detectable limit for this assay was $0.30 \mathrm{pg} / \mathrm{mL}$.

Concentrations of $\mathrm{P} 4$ in plasma were determined using a commercially available solid-phase RIA (CoatA-Count Progesterone; Diagnostic Products Corp., Los Angeles, CA). The mean interassay and intra-assay coefficients of variation for high-quality control samples were 7.62 and $6.70 \%$, respectively, with a mean concentration of $6.85 \mathrm{ng} / \mathrm{mL}$. The minimum detectable limit for this assay was $0.12 \mathrm{ng} / \mathrm{mL}$.

\section{Milk Yield, Composition, BW, and BCS}

Cows were milked twice daily at 0700 and $1600 \mathrm{~h}$. Individual milk yields $(\mathrm{kg})$ were recorded automatically at each milking (Dairymaster, Causeway, Co. Kerry, Ireland). Milk fat, protein, and lactose concentrations were calculated weekly from 1 successive evening and morning milk sample for each animal. Near-infrared reflectance spectroscopy (Milkoscan 203; Foss Electric, Hillerød, Denmark) was used to determine the concentrations of constituents in the milk. All cows were weighed weekly. Body condition score was recorded weekly, by 1 experienced independent observer, on a scale from 1 (emaciated) to 5 (extremely obese), with increments of 0.25 (Edmonson et al., 1989).

\section{Data Handling}

When an animal had more than 1 follicle $\geq 10 \mathrm{~mm}$ present on the ovary at the onset of synchronization treatments, only the diameter of the follicle $(\geq 10 \mathrm{~mm})$ that ovulated was included in the analysis. When an animal had more than 1 follicle $\geq 10 \mathrm{~mm}$ present on the ovary at the onset of synchronization treatments and failed to ovulate to GnRH1 of synchronization treatments, the diameter of the largest follicle $(\geq 10$ $\mathrm{mm}$ ) was included in the analysis. When an animal had more than 1 CL present on the ovary at the onset of synchronization treatments, the diameter of the largest CL was included in the analysis of CL diameter. When an animal had more than 1 ovulation at synchronized estrous, the combined volume of all CL were included in the analysis of postovulatory CL volume.

\section{Animals Removed From Data Analysis}

Initially, 64 animals were enrolled in the study. Animals $(\mathrm{n}=3)$ treated with CIDR_OBS that failed to ovulate on the presumptive day of estrus or within $3 \mathrm{~d}$ after the presumptive day of estrus were subsequently removed from the data analysis. Animals treated with CIDR_TAI $(\mathrm{n}=2)$ and Ovsynch $(\mathrm{n}=2)$ that failed to undergo complete luteal regression $(\mathrm{P} 4 \geq 1.0 \mathrm{ng} / \mathrm{mL} 48$ $\mathrm{h}$ after PGF injection) in response to PGF on $\mathrm{d} 7$ of the synchronization treatment were subsequently removed from the analysis. After these exclusions, the final data set included 57 cows (26 multiparous and 31 primiparous). The numbers of animals reported per treatment were as follows: CIDR_OBS $(\mathrm{n}=19)$, CIDR_TAI $(\mathrm{n}=$ 18), and Ovsynch $(\mathrm{n}=20)$.

\section{Statistical Analyses}

All statistical analyses were completed using SAS (SAS Institute, 2006). Data were checked for normality and homogeneity of variance using histograms, quantile-quantile (Q-Q) plots, and formal statistical tests in the UNIVARIATE and GLM procedures of SAS. Variables with a non-normal distribution were log transformed before analysis. Continuous variables, including dominant follicle diameter, CL diameter, luteal volume, interval to ovulation following PGF injection, and individual time points for circulating concentrations of P4 and E2 were analyzed using mixed models, with treatment $(\mathrm{n}=3)$, parity $(1,>1)$, replicate (n $=3$ ), and calving date as fixed effects, and block as a 
random effect. Biologically plausible interactions were tested for significance in the model for each dependent variable. Fixed effects $(P>0.05)$ and interactions $(P>$ $0.10)$ not associated with the dependent variables were removed by backward elimination with the exception of treatment and parity, which were forced into each model. Differences between treatments were declared significant when $P \leq 0.05$, and a tendency toward significance was assumed when $0.05<P \leq 0.10$. Differences between least squares means were compared using the Tukey option to adjust for multiple comparisons. Preplanned contrasts were used to compare treatments to synchronize estrus with treatments to synchronize ovulation for specific individual time points of interest. All results are reported as least squares means and standard error of the means for untransformed data and back-transformed least squares means and 95\% confidence intervals for log-transformed data.

Linear interpolation was performed using the TRANSREG procedure of SAS and was used to calculate values for every day of the study for postovulatory P4 concentrations and postovulatory luteal volume. Animals $(\mathrm{n}=4)$ with missing values at any time point for postovulatory luteal volume were removed. Circulating postovulatory $\mathrm{P} 4$ and preovulatory E2 concentrations and luteal volume profiles for each treatment were analyzed using mixed models with repeated measures. Treatment $(\mathrm{n}=3)$, time, parity $(1,>1)$, replicate (n $=3$ ), and calving date were included as fixed effects and block as a random effect. All models with repeated measures included the effect of time and the interaction between treatment and time. The Satterthwaite adjustment was used to calculate denominator degrees of freedom and a first-order autoregressive covariance structure (AR1) was used. The appropriate covariance structure for each repeated measures analysis was identified based on the Akaike Information Criterion (AIC) model fit statistic. Binomial response data including presence or absence of a CL at GnRH1, ovulation rate to GnRH1, and cumulative proportion of cows with follicles ovulating at different intervals following PGF injection were compared using the Fisher Exact Test.

Multiple linear regression (PROC REG) and the stepwise variable selection procedure were used to generate a model containing independent variables that were most effective at predicting peak circulating concentrations of $\mathrm{E} 2$ and preovulatory follicle diameter. The independent variables tested for peak circulating concentrations of E2 related to treatment, parity, DIM, milk production, BW, BCS, ovarian status at treatment initiation, preovulatory dominant follicle diameter, preovulatory concentrations of $\mathrm{P} 4$, and timing of ovulation. The independent variables tested for preovulatory dominant follicle diameter were identical to those tested for peak circulating concentrations of E2, with the exception that the dominant follicleindependent variables were removed, and independent variables relating to preovulatory concentrations of E2 were included. The significance level for entry and the significance level to stay in the model were both set at $P \leq 0.05$. Nonlinear associations between continuous variables and both peak circulating concentrations of E2 and preovulatory follicle diameter were also tested. Multicollinearity between predictor variables in the final model was examined using the variance inflation factor test.

\section{RESULTS}

\section{Ovarian Status at Treatment Initiation}

The details of the ovarian structures present and the ovulatory response to GnRH1 is summarized in Table 1. A difference $(P=0.03)$ between treatments in dominant follicle diameter at GnRH1 was observed. The dominant follicle diameter was larger $(P=0.04)$ for CIDR_OBS compared with Ovsynch, and tended $(P=0.06)$ to be larger for CIDR_OBS compared with CIDR_TAI. However, no differences $(P=0.3)$ were observed between synchronization treatments in the ovulatory response to GnRH1. Across all cows in the study, $72 \%$ of animals ovulated in response to GnRH1. No difference $(P=0.3)$ was observed between treatments in the proportion of cows with a CL present or in CL diameter $(P=0.3)$ at GnRH1. The diameter of the CL at treatment initiation was lesser $(P=0.009)$ in animals treated with CIDR_TAI that ovulated in response to GnRH1.

\section{Preovulatory Circulating Progesterone Concentrations}

No differences $(P=0.2)$ between treatments in mean circulating P4 concentrations (95\% CI) were observed at the onset of synchronization treatments [2.96 (1.21, 7.21), $0.94(0.38,2.36)$, and $1.52(0.64,3.64) \mathrm{ng} / \mathrm{mL}$ for CIDR_OBS, CIDR_TAI, and Ovsynch, respectively]. By $24 \mathrm{~h}$ after CIDR insertion, circulating P4 concentrations were greater $(P=0.007)$ for CIDR-based treatments compared with Ovsynch $[5.34(2.85,10.00)$ and $4.98(2.62,9.48)$ vs. $1.75(0.93,3.28) \mathrm{ng} / \mathrm{mL}$ for CIDR_OBS and CIDR_TAI vs. Ovsynch, respectively]. Similarly, by $24 \mathrm{~h}$ after PGF injection (immediately before CIDR removal) circulating concentrations of $\mathrm{P} 4$ were greater $(P<0.001)$ for CIDR-based treatments compared with Ovsynch $[1.65(1.25,2.18)$ and 1.48 $(1.11,1.97)$ vs. $0.40(0.30,0.53) \mathrm{ng} / \mathrm{mL}$ for CIDR_OBS and CIDR_TAI vs. Ovsynch, respectively]. By $12 \mathrm{~h}$ 
Table 1. Ovarian characteristics at treatment initiation

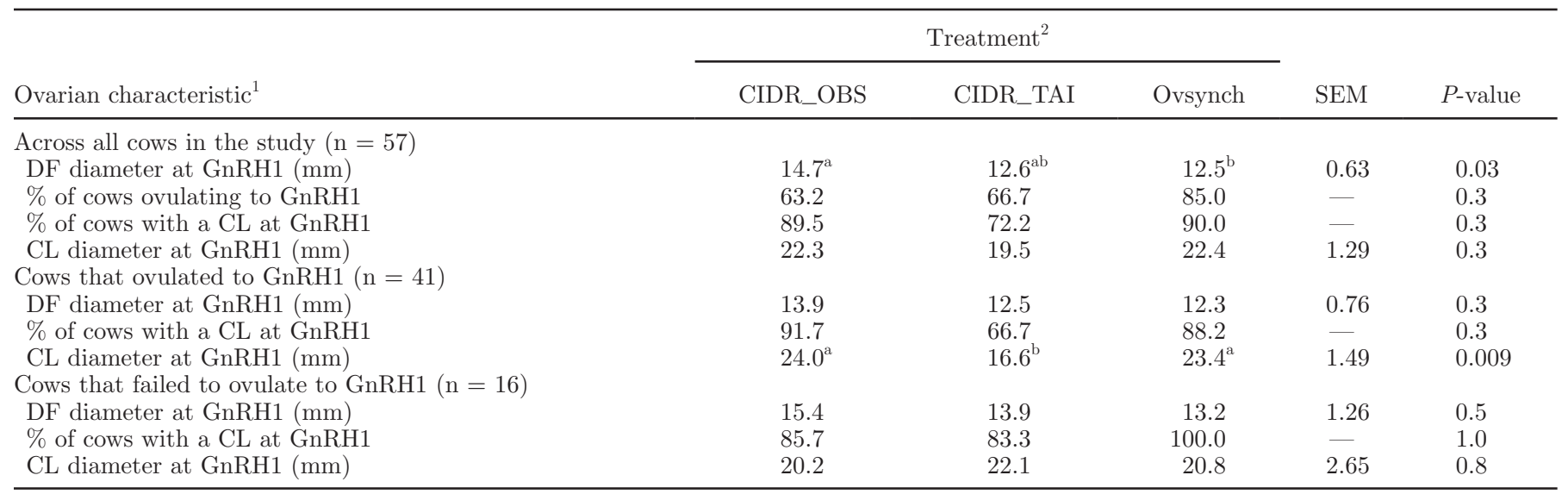

\footnotetext{
${ }^{a, b}$ Least squares means within a row with different superscript letters differ $(P<0.05)$.

${ }^{1} \mathrm{DF}=$ dominant follicle; $\mathrm{CL}=$ corpus luteum.

${ }^{2} \mathrm{CIDR}=$ controlled internal drug release OBS $=$ observed estrus; TAI = timed AI. Synchronization treatments were initiated at a random stage of the estrous cycle and applied to lactating dairy cows before the first service. CIDR_OBS $=10 \mu \mathrm{g}$ of GnRH and CIDR insert at d 0,25 mg of $\mathrm{PGF}_{2 \alpha}$ at $\mathrm{d} 7$, CIDR removed at d 8; animals were inseminated by the a.m./p.m. rule following detection of estrus on d 10, 11 , and 12 . CIDR_TAI $=10 \mu \mathrm{g}$ of $\mathrm{GnRH}$ and CIDR insert at d $0,25 \mathrm{mg}$ of $\mathrm{PGF}_{2 \alpha}$ at d 7, CIDR removed at d 8, $10 \mu \mathrm{g}$ of $\mathrm{GnRH} 60 \mathrm{~h}$ after PGF $2 \alpha$ injection or $36 \mathrm{~h}$ after CIDR removal; animals received TAI $18 \mathrm{~h}$ after the final $\mathrm{GnRH}$ injection. Ovsynch $=10 \mu \mathrm{g}$ of $\mathrm{GnRH}$ at d $0,25 \mathrm{mg}$ of PGF $2 \alpha$ at d 7, $10 \mu \mathrm{g}$ of $\mathrm{GnRH} 60 \mathrm{~h}$ after $\mathrm{PGF}_{2 \alpha}$ injection; animals received TAI $18 \mathrm{~h}$ after the final $\mathrm{GnRH}$ injection.
}

after CIDR removal, no differences $(P=0.8)$ between treatments in circulating concentrations of $\mathrm{P} 4$ were observed $[0.16(0.10,0.26), 0.13(0.08,0.21)$, and 0.13 $(0.08,0.21) \mathrm{ng} / \mathrm{mL}$ for CIDR_OBS, CIDR_TAI, and Ovsynch, respectively]. Circulating concentrations of P4 were not different $(P=0.2)$ between treatments on the day of presumptive estrus $[0.06(0.04,0.10), 0.03$ $(0.02,0.05)$, and $0.04(0.03,0.07) \mathrm{ng} / \mathrm{mL}$ for CIDR OBS, CIDR_TAI, and Ovsynch, respectively].

\section{Dominant Follicle Diameter}

The effect of synchronization treatment on dominant follicle measurements is summarized in Table 2 . Synchronization treatment had no effect $(P=0.9)$ on dominant follicle diameter $24 \mathrm{~h}$ after PGF injection. The dominant follicle diameter at $80 \mathrm{~h}$ after PGF injection (22 h after GnRH2 for CIDR_TAI and Ovsynch) was greater $(P=0.05)$ for CIDR_TAI compared with Ovsynch, but CIDR_OBS was not different from

Table 2. Effect of synchronization treatment on mean (pooled SEM) dominant follicle (DF) diameter during synchronization

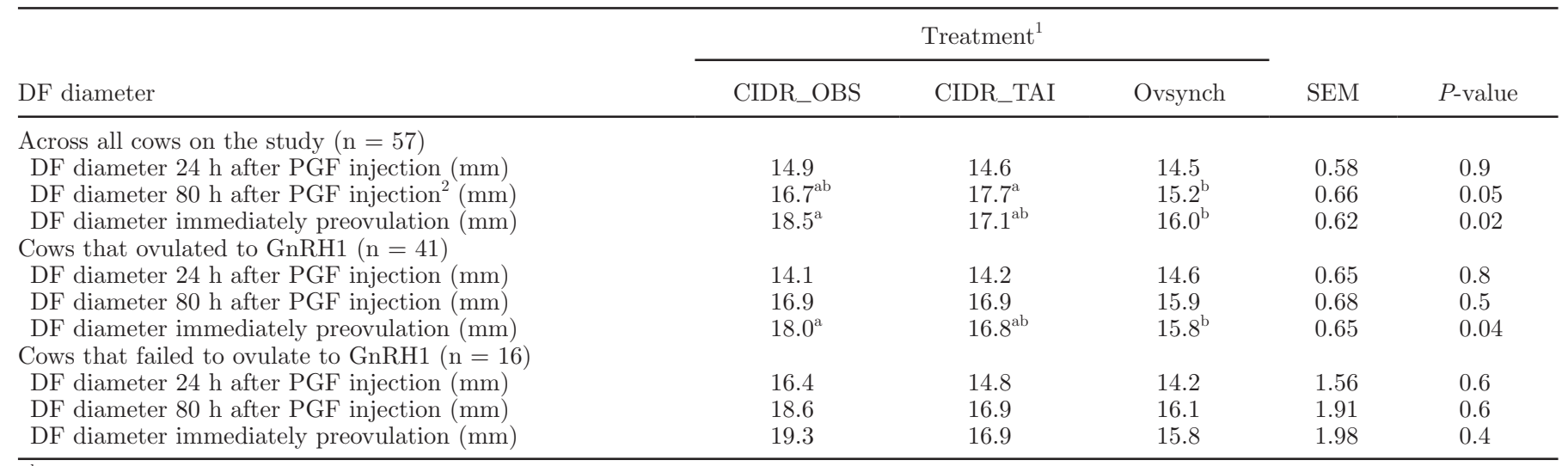

${ }^{\mathrm{a}, \mathrm{b}}$ Least squares means within a row with different superscript letters differ $(P<0.05)$.

${ }^{1} \mathrm{CIDR}=$ controlled internal drug release; OBS = observed estrus; TAI = timed AI. Synchronization treatments were initiated at a random stage of the estrous cycle and applied to lactating dairy cows before the first service. CIDR_OBS $=10 \mu \mathrm{g}$ of GnRH and CIDR insert at d 0,25 $\mathrm{mg}$ of $\mathrm{PGF}_{2 \alpha}$ at d 7, CIDR removed at d 8; animals were inseminated by the a.m./p.m. rule following detection of estrus on $\mathrm{d} 10,11$, and 12 . CIDR_TAI $=10 \mu \mathrm{g}$ of $\mathrm{GnRH}$ and CIDR insert at d $0,25 \mathrm{mg}$ of $\mathrm{PGF}_{2 \alpha}$ at d 7, CIDR removed at d 8, $10 \mu \mathrm{g}$ of GnRH $60 \mathrm{~h}$ after PGF $\mathrm{C}_{2 \alpha}$ injection or $36 \mathrm{~h}$ after CIDR removal; animals received TAI $18 \mathrm{~h}$ after the final $\mathrm{GnRH}$ injection. Ovsynch $=10 \mu \mathrm{g}$ of $\mathrm{GnRH}_{\text {at }} \mathrm{d} 0,25 \mathrm{mg}$ of PGF $2 \alpha$ at d 7, $10 \mu \mathrm{g}$ of $\mathrm{GnRH} 60 \mathrm{~h}$ after $\mathrm{PGF}_{2 \alpha}$ injection; animals received TAI $18 \mathrm{~h}$ after the final $\mathrm{GnRH}$ injection.

${ }^{2}$ Twenty-two hours after GnRH2 for CIDR_TAI and Ovsynch. 
CIDR_TAI $(P=0.6)$ or Ovsynch $(P=0.2)$. The peak preovulatory follicle diameter was greater $(P=0.02)$ for CIDR_OBS compared with Ovsynch, but neither treatment differed from CIDR_TAI.

\section{Preovulatory Circulating Estradiol Concentrations}

The effect of synchronization treatment on mean circulating E2 concentrations is summarized in Table 3 and Figure 2. Circulating E2 concentrations were greater $(P<0.05)$ in CIDR_OBS at all time points from $36 \mathrm{~h}$ after PGF compared with Ovsynch, and was greater $(P<0.001)$ at $72 \mathrm{~h}$ after PGF compared with the CIDR_TAI treatment. Peak circulating concentrations of E2 were greater $(P=0.004)$ for CIDR_OBS compared with Ovsynch, and tended $(P=0.10)$ to be greater compared with CIDR_TAI. No difference $(P=$ 0.9 ) was observed in the interval from PGF injection to peak circulating E2 between CIDR_TAI and Ovsynch. Both CIDR_TAI $(P=0.008)$ and Ovsynch $(P=0.002)$ had shorter intervals from PGF injection to peak circulating E2 concentrations compared with CIDR_OBS.

\section{Timing of Ovulation}

All animals treated with CIDR_TAI and Ovsynch successfully ovulated in response to GnRH2. Three animals treated with CIDR_OBS failed to ovulate on the presumptive day of estrus or within $3 \mathrm{~d}$ after the presumptive day of estrus (not included in the analysis). The effect of synchronization treatment on the cumulative proportion of cows with follicles ovulating at different intervals following PGF is summarized in Figure 3. No difference $(P=0.12)$ was observed in the proportion of cows with follicles ovulating by $76 \mathrm{~h}$ after PGF injection. By 84 to $92 \mathrm{~h}$ after PGF injection, all animals treated with CIDR_TAI and Ovsynch had ovulated. In contrast, at $92 \mathrm{~h}$ after PGF injection, 0.53 of animals treated with CIDR_OBS had ovulated. By $116 \mathrm{~h}$ after PGF injection, treatment differences were no longer significant $(P=0.6)$. By $140 \mathrm{~h}$ after PGF injection, all animals treated with CIDR_OBS that would ultimately ovulate the dominant follicle had done so. Synchronization treatment had an effect $(P<0.001)$ on the interval from PGF injection to ovulation. The mean interval from PGF injection to ovulation was longer for CIDR_OBS $(100.0 \mathrm{~h})$ compared with CIDR_TAI and Ovsynch (84.4 and $83.2 \mathrm{~h}$, respectively; both $P<0.001$ ).

\section{Postovulatory Circulating Progesterone and Luteal Volume}

The effect of synchronization treatment on postovulatory $\mathrm{P} 4$ concentration profiles and luteal volume pro-

Table 3. Effect of synchronization treatment on mean (95\% CI) preovulatory concentrations of estradiol (E2; $\mathrm{pg} / \mathrm{mL})$

\begin{tabular}{|c|c|c|c|c|c|}
\hline \multirow[b]{2}{*}{ Item } & \multicolumn{3}{|c|}{ Treatment $^{1}$} & \multirow[b]{2}{*}{ SEM } & \multirow[b]{2}{*}{$P$-value } \\
\hline & CIDR_OBS & CIDR_TAI & Ovsynch & & \\
\hline \multicolumn{6}{|l|}{ E2 concentration } \\
\hline Time of PGF injection & $\begin{array}{l}0.72 \\
(0.43,1.22)\end{array}$ & $\begin{array}{l}0.60 \\
(0.35,1.03)\end{array}$ & $\begin{array}{l}0.49 \\
(0.29,0.81)\end{array}$ & - & 0.6 \\
\hline $24 \mathrm{~h}$ after PGF & $\begin{array}{l}1.84 \\
(1.38,2.45)\end{array}$ & $\begin{array}{l}1.42 \\
(1.06,1.91)\end{array}$ & $\begin{array}{l}1.26 \\
(0.95,1.67)\end{array}$ & - & 0.17 \\
\hline $36 \mathrm{~h}$ after $\mathrm{PGF}$ injection ${ }^{2}$ & $\begin{array}{l}2.46^{\mathrm{a}} \\
(1.87,3.23)\end{array}$ & $\begin{array}{l}1.87^{\mathrm{ab}} \\
(1.41,2.47)\end{array}$ & $\begin{array}{l}1.48^{\mathrm{b}} \\
(1.13,1.93)\end{array}$ & - & 0.03 \\
\hline $60 \mathrm{~h}$ after $\mathrm{PGF}$ injection ${ }^{3}$ & $\begin{array}{l}2.47^{\mathrm{a}} \\
(1.78,3.42)\end{array}$ & $\begin{array}{l}2.04^{\mathrm{ab}} \\
(1.45,2.87)\end{array}$ & $\begin{array}{l}1.37^{\mathrm{b}} \\
(1.00,1.89)\end{array}$ & - & 0.03 \\
\hline $72 \mathrm{~h}$ after $\mathrm{PGF}$ injection ${ }^{4}$ & $\begin{array}{l}1.88^{\mathrm{a}} \\
(1.48,2.39)\end{array}$ & $\begin{array}{l}0.40^{\mathrm{b}} \\
(0.30,0.52)\end{array}$ & $\begin{array}{l}0.30^{b} \\
(0.24,0.38)\end{array}$ & - & $<0.001$ \\
\hline Peak preovulatory E2 concentration & $\begin{array}{l}3.85^{\mathrm{a}} \\
(3.10,4.78)\end{array}$ & $\begin{array}{l}2.82^{\mathrm{ab}} \\
(2.26,3.52)\end{array}$ & $\begin{array}{l}2.39^{\mathrm{b}} \\
(1.93,2.95)\end{array}$ & - & 0.006 \\
\hline Time of peak E2 relative to PGF (h) & $67.8^{\mathrm{a}}$ & $52.1^{\mathrm{b}}$ & $49.8^{\mathrm{b}}$ & 3.52 & 0.001 \\
\hline
\end{tabular}

$\overline{\mathrm{a}, \mathrm{b}}$ Least squares means within a row with different superscript letters differ $(P<0.05)$.

${ }^{1} \mathrm{CIDR}=$ controlled internal drug release; OBS $=$ observed estrus; TAI $=$ timed AI. Synchronization treatments were initiated at a random stage of the estrous cycle and applied to lactating dairy cows before the first service. CIDR_OBS $=10 \mu \mathrm{g}$ of $\mathrm{GnRH}$ and CIDR insert at d 0,25 $\mathrm{mg}$ of $\mathrm{PGF}_{2 \alpha}$ at d 7, CIDR removed at d 8; animals were inseminated by the a.m./p.m. rule following detection of estrus on d 10, 11, and 12. CIDR_TAI $=10 \mu \mathrm{g}$ of GnRH and CIDR insert at d $0,25 \mathrm{mg}$ of $\mathrm{PGF}_{2 \alpha}$ at $\mathrm{d} 7$, CIDR removed at $\mathrm{d} 8,10 \mu \mathrm{g}$ of $\mathrm{GnRH} 60$ $\mathrm{h}$ after $\mathrm{PGF}_{2 \alpha}$ injection or $36 \mathrm{~h}$ after CIDR removal; animals received TAI $18 \mathrm{~h}$ after the final GnRH injection. Ovsynch $=10 \mu \mathrm{g}$ of $\mathrm{GnRH}$ at d $0,25 \mathrm{mg}$ of $\mathrm{PGF}_{2 \alpha}$ at d 7, $10 \mu \mathrm{g}$ of $\mathrm{GnRH} 60 \mathrm{~h}$ after $\mathrm{PGF}_{2 \alpha}$ injection; animals received TAI $18 \mathrm{~h}$ after the final GnRH injection.

${ }^{2}$ Twelve hours after CIDR removal for CIDR_OBS and CIDR_TAI.

${ }^{3}$ Time of GnRH2 for CIDR_TAI and Ovsynch.

${ }^{4}$ Twelve hours after GnRH2 for CIDR_TAI and Ovsynch. 


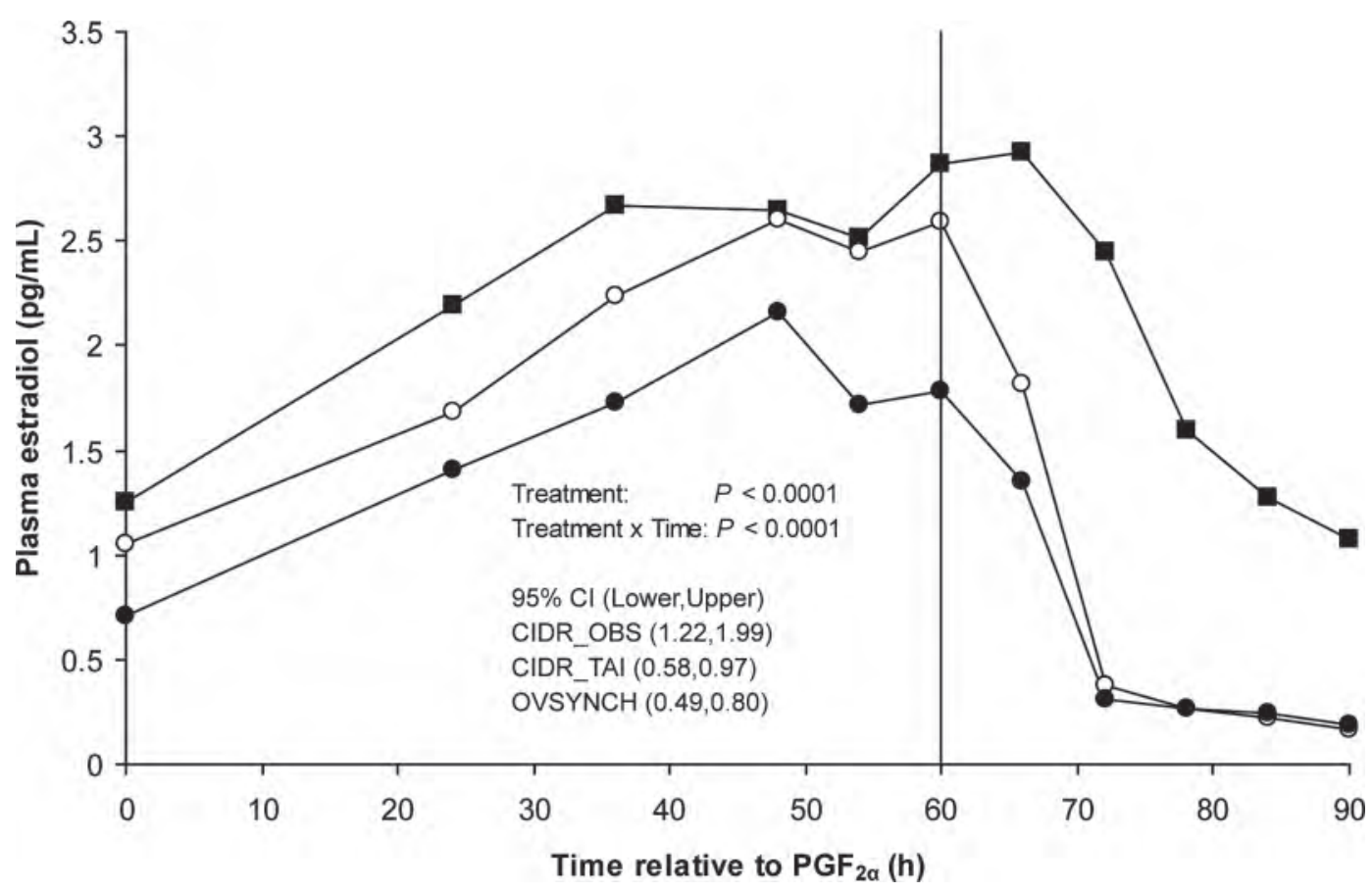

Figure 2. Effect of synchronization treatment on mean (95\% CI) estradiol concentrations $(\mathrm{pg} / \mathrm{mL})$ from the time of $\mathrm{PGF} \mathrm{F}_{2 \alpha}$ injection until 90 $\mathrm{h}$ following $\mathrm{PGF}_{2 \alpha}$ for CIDR_OBS $(\boldsymbol{\square})$, CIDR_TAI $(\mathrm{O})$, and Ovsynch $(\bullet)$. The vertical line at $60 \mathrm{~h}$ represents the timing of GnRH2 for animals treated with CIDR_TAI and Ovsynch. Log-transformed data was used to calculate $P$-values. Least squares means of the nontransformed data were used to generate this figure. CIDR $=$ controlled internal drug release; OBS = observed estrus; TAI = timed AI. Synchronization treatments were initiated at a random stage of the estrous cycle and applied to lactating dairy cows before the first service. CIDR_OBS $=10 \mu \mathrm{g}$ of GnRH and CIDR insert at d 0, $25 \mathrm{mg}$ of $\mathrm{PGF}_{2 \alpha}$ at d 7, CIDR removed at d 8; animals were inseminated by the a.m./p.m. rule following detection of estrus on $\mathrm{d} 10,11$, and 12 . CIDR_TAI $=10 \mu \mathrm{g}$ of GnRH and CIDR insert at d $0,25 \mathrm{mg}$ of $\mathrm{PGF}_{2 \alpha}$ at d 7 , CIDR removed at d 8, $10 \mu \mathrm{g}$ of GnRH $60 \mathrm{~h}$ after $\mathrm{PGF}_{2 \alpha}$ injection or $36 \mathrm{~h}$ after CIDR removal; animals received TAI $18 \mathrm{~h}$ after the final GnRH injection. Ovsynch $=10 \mu \mathrm{g}$ of $\mathrm{GnRH}$ at d 0, $25 \mathrm{mg}$ of $\mathrm{PGF}_{2 \alpha}$ at d 7, $10 \mu \mathrm{g}$ of $\mathrm{GnRH} 60 \mathrm{~h}$ after $\mathrm{PGF}_{2 \alpha}$ injection; animals received TAI $18 \mathrm{~h}$ after the final GnRH injection.

files is summarized in Figure 4. No differences between treatments in mean circulating $\mathrm{P} 4(P=0.4)$ from the day of ovulation until d 14 after ovulation or in mean luteal volume $(P=0.5)$ from d 4 after ovulation until d 15 after ovulation were detected. No treatment by time interactions were observed for postovulatory $\mathrm{P} 4(P=$ $0.4)$ or luteal volume $(P=0.2)$.

\section{Multiple Linear Regression Analysis}

Peak Circulating Concentrations of E2. The multiple linear regression model containing independent variables selected for predicting peak circulating concentrations of E2 is summarized in Table 4. Dominant follicle diameter pre-ovulation, the nonlinear (quadratic) term for dominant follicle diameter preovulation, and DIM at the start of treatment were associated with peak circulating concentrations of E2 (model $\mathrm{R}^{2}=0.54$ ).

Preovulatory Follicle Diameter. The multiple linear regression model containing independent variables selected for predicting preovulatory follicle diameter is summarized in Table 4. Peak circulating concentrations of E2, cumulative milk yield from wk 2 to 5 of lacta- tion, and the nonlinear (quadratic) term for cumulative milk yield from wk 2 to 5 of lactation were associated with preovulatory follicle diameter $\left(\right.$ model $\left.R^{2}=0.58\right)$.

\section{DISCUSSION}

This study provides evidence for differences in periovulatory E2 concentrations between treatments to synchronize estrus and ovulation. Periovulatory E2 concentrations were greater for CIDR_OBS compared with Ovsynch. Administration of GnRH2 caused an abrupt decrease in circulating E2 concentrations, and resulted in a narrow range in time to ovulation for CIDR_TAI and Ovsynch. In contrast, more variability in the time of ovulation, greater preovulatory follicle size, and greater periovulatory circulating concentrations of E2 were observed for CIDR_OBS.

In the present study, synchronization treatments were initiated at random stages of the estrous cycle with no presynchronization. Differences between treatments existed in dominant follicle diameter at GnRH1 but this did not affect the ovulatory response. Vasconcelos et al. (1999) reported that cows initiating the Ovsynch treatment during early to mid diestrus (d 5 to 12 of the 


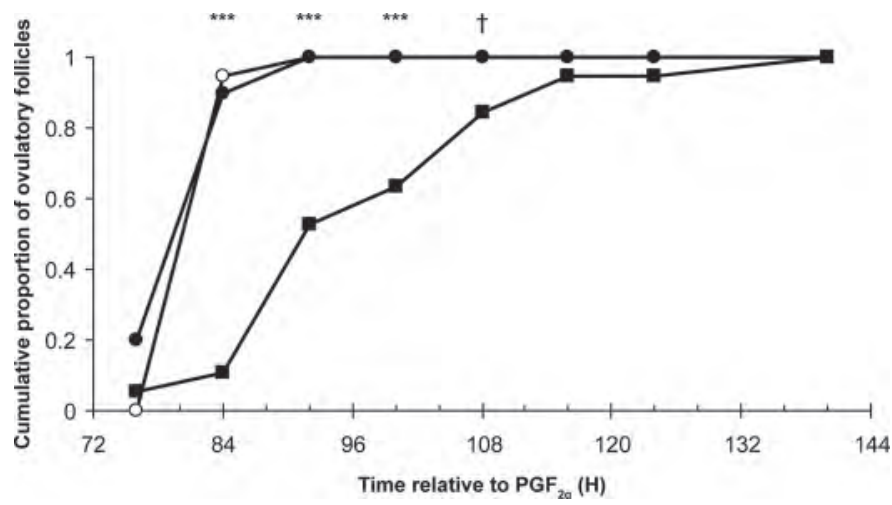

Figure 3. Effect of synchronization treatment on the cumulative proportion of cows with follicles ovulating at different intervals following $\mathrm{PGF}_{2 \alpha}$ injection for CIDR_OBS (ם), CIDR_TAI (O), and Ovsynch $(\bullet)$. CIDR $=$ controlled internal drug release; OBS $=$ observed estrus; TAI $=$ timed AI. ${ }^{* * *}$ indicates treatment effect at $P<0.001 ; \dagger$ indicates treatment effect at $P=0.06$. Synchronization treatments were initiated at a random stage of the estrous cycle and applied to lactating dairy cows before the first service. CIDR_OBS $=10 \mu \mathrm{g}$ of $\mathrm{GnRH}$ and CIDR insert at $\mathrm{d}$ 0,25 $\mathrm{mg}$ of $\mathrm{PGF}_{2 \alpha}$ at $\mathrm{d}$ 7, CIDR removed at $\mathrm{d}$ 8; animals were inseminated by the a.m./p.m. rule following detection of estrus on d 10,11, and 12. CIDR_TAI $=10 \mu \mathrm{g}$ of GnRH and CIDR insert at $\mathrm{d}$ 0, $25 \mathrm{mg}$ of $\mathrm{PGF}_{2 \alpha}$ at $\mathrm{d}$ 7, CIDR removed at $\mathrm{d} 8,10 \mu \mathrm{g}$ of GnRH $60 \mathrm{~h}$ after $\mathrm{PGF}_{2 \alpha}$ injection or $36 \mathrm{~h}$ after CIDR removal; animals received TAI $18 \mathrm{~h}$ after the final GnRH injection. Ovsynch $=10 \mu \mathrm{g}$ of GnRH at $\mathrm{d} 0,25 \mathrm{mg}$ of $\mathrm{PGF}_{2 \alpha}$ at $\mathrm{d}$ 7, $10 \mu \mathrm{g}$ of $\mathrm{GnRH} 60 \mathrm{~h}$ after $\mathrm{PGF}_{2 \alpha}$ injection; animals received TAI $18 \mathrm{~h}$ after the final $\mathrm{GnRH}$ injection.

estrous cycle), when they had an active CL and serum P4 concentrations were high, had smaller ovulatory follicles, improved ovulatory responses to GnRH1, and greater conception rates than cows initiating Ovsynch during metestrus, late diestrus, or proestrus. Ovulatory responses to GnRH1 in the present study were consistent with previous studies where estrous cycles were not presynchronized (Pursley et al., 1995; Vasconcelos et al., 1999; Bello et al., 2006). In the current study, the presence of a CL was used as a proxy for cycling status at onset of synchronization treatments. Stevenson et al. (2008) reported an overall accuracy of $84 \%$ with this technique for estimating prior luteal activity. The incidence of anovulation in the present study was less than the incidence of $23.3 \%$ reported by Bamber et al. (2009) for high-producing lactating dairy cows treated with treatments to synchronize estrus or ovulation in the United States. Anovulation has been associated with a decreased probability of conception and an increased incidence of embryo loss associated with Ovsynch treatments (Gümen et al., 2003). Thus, anovulation at the end of the voluntary waiting period among high-producing lactating dairy cows in the United States contributes to the impaired reproductive performance that is observed when cows are inseminated after TAI (Gümen et al., 2003).

Supplementation with P4 increased circulating P4 concentrations within $24 \mathrm{~h}$ in animals treated with
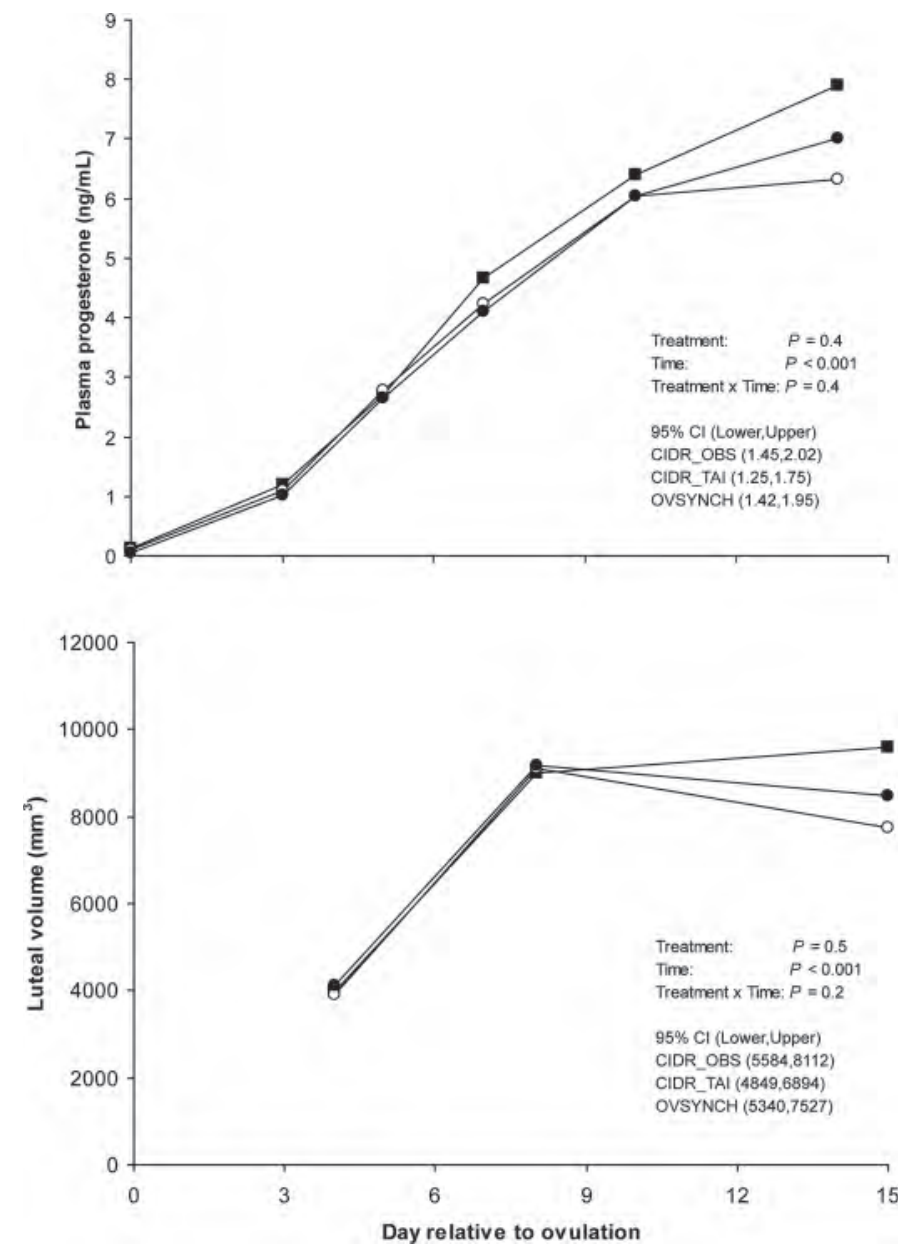

Figure 4. Effect of synchronization treatment on mean P4 concentrations $(\mathrm{ng} / \mathrm{mL})$ from the day of ovulation until d 14 after ovulation and mean luteal volume $\left(\mathrm{mm}^{3}\right)$ from d 4 after ovulation until d 15 after ovulation for CIDR_OBS $(\mathbf{\square})$, CIDR_TAI (O), and Ovsynch $(\bullet)$. Log-transformed data was used to calculate $P$-values and least squares means of the nontransformed data were used to generate this figure. $\mathrm{CIDR}=$ controlled internal drug release; OBS $=$ observed estrus; TAI $=$ timed AI. Synchronization treatments were initiated at a random stage of the estrous cycle and applied to lactating dairy cows before the first service. CIDR_OBS $=10 \mu \mathrm{g}$ of GnRH and CIDR insert at d $0,25 \mathrm{mg}$ of $\mathrm{PGF}_{2 \alpha}$ at $\mathrm{d} 7$, CIDR removed at d 8; animals were inseminated by the a.m./p.m. rule following detection of estrus on d 10, 11 , and 12. CIDR_TAI $=10 \mu \mathrm{g}$ of GnRH and CIDR insert at d 0,25 $\mathrm{mg}$ of $\mathrm{PGF}_{2 \alpha}$ at $\mathrm{d} 7$, CIDR removed at $\mathrm{d} 8,10 \mu \mathrm{g}$ of $\mathrm{GnRH} 60 \mathrm{~h}$ after $\mathrm{PGF}_{2 \alpha}$ injection or $36 \mathrm{~h}$ after CIDR removal; animals received TAI 18 $\mathrm{h}$ after the final $\mathrm{GnRH}$ injection. Ovsynch $=10 \mu \mathrm{g}$ of $\mathrm{GnRH}$ at $\mathrm{d} 0$, $25 \mathrm{mg}$ of $\mathrm{PGF}_{2 \alpha}$ at $\mathrm{d} 7,10 \mu \mathrm{g}$ of $\mathrm{GnRH} 60 \mathrm{~h}$ after $\mathrm{PGF}_{2 \alpha}$ injection; animals received TAI $18 \mathrm{~h}$ after the final $\mathrm{GnRH}$ injection.

CIDR_OBS and CIDR_TAI compared with animals treated with Ovsynch. Importantly, by $24 \mathrm{~h}$ after PGF injection (immediately before CIDR removal), circulating P4 concentrations were greater for CIDR_OBS and CIDR_TAI compared with Ovsynch. Thus, animals treated with CIDR_OBS and CIDR_TAI were exposed to greater circulating $\mathrm{P} 4$ concentrations for a longer time frame during the period of ovulatory follicle growth 
Table 4. Multiple linear regression models for peak circulating concentrations of estradiol (E2) and preovulatory follicle diameter ${ }^{1}$

\begin{tabular}{|c|c|c|c|c|c|c|}
\hline Item & \multicolumn{3}{|c|}{ Peak circulating concentration of E2 } & \multicolumn{3}{|c|}{ Preovulatory follicle diameter } \\
\hline Model $\mathrm{R}^{2}$ & & 0.54 & & & 0.58 & \\
\hline
\end{tabular}

${ }^{1}$ Three synchronization treatments were initiated at a random stage of the estrous cycle and applied to lactating dairy cows before the first service. Definitions for terms used in the treatments: CIDR $=$ controlled internal drug release; OBS $=$ observed estrus; TAI $=$ timed AI. CIDR $\mathrm{OBS}=10 \mu \mathrm{g}$ of $\mathrm{GnRH}$ and CIDR insert at $\mathrm{d} 0,25 \mathrm{mg}$ of $\mathrm{PGF}_{2 \alpha}$ at $\mathrm{d} 7$, CIDR removed at d 8; animals were inseminated by the a.m./p.m. rule following detection of estrus on $\mathrm{d} 10,11$, and 12 . CIDR_TAI $=10 \mu \mathrm{g}$ of GnRH and CIDR insert at d $0,25 \mathrm{mg}$ of PGF $2 \alpha$ at $\mathrm{d} 7, \mathrm{CIDR}$ removed at d 8, $10 \mu \mathrm{g}$ of $\mathrm{GnRH} 60 \mathrm{~h}$ after $\mathrm{PGF}_{2 \alpha}$ injection or $36 \mathrm{~h}$ after CIDR removal; animals received TAI $18 \mathrm{~h}$ after the final GnRH injection. Ovsynch $=10 \mu \mathrm{g}$ of $\mathrm{GnRH}$ at d $0,25 \mathrm{mg}$ of $\mathrm{PGF}_{2 \alpha}$ at d 7, $10 \mu \mathrm{g}$ of $\mathrm{GnRH} 60 \mathrm{~h}$ after $\mathrm{PGF}_{2 \alpha}$ injection; animals received TAI $18 \mathrm{~h}$ after the final GnRH injection.

${ }^{2}$ Nonlinear association between peak circulating concentrations of E2 and preovulatory follicle diameter.

${ }^{3}$ Peak E2 = log-transformed data.

${ }^{4}$ Nonlinear association between preovulatory follicle diameter and cumulative milk yield from wk 2 to 5 of lactation.

and development compared with animals treated with Ovsynch. Revah and Butler (1996) reported that lesser $\mathrm{P} 4$ concentrations in the cycle preceding ovulation may allow increased LH pulse frequency, thereby increasing the risk of excessive stimulation of the follicle and premature activation of the oocyte, and thus increased risk of inferior oocyte quality before ovulation and poor embryo quality after fertilization (Ahmad et al., 1995).

In the present study, the diameter of the dominant follicle pre-ovulation was greater for CIDR_OBS compared with Ovsynch. Bello et al. (2006) reported that an ovulatory follicle diameter at the time of GnRH2 of Ovsynch of approximately $16 \mathrm{~mm}$ was most likely to lead to a successful pregnancy. Other studies have reported that larger (Lopes et al., 2007) or smaller (Vasconcelos et al., 1999) preovulatory follicle diameter resulted in improved pregnancy outcomes following Ovsynch. Excessively small ovulatory follicle size was also associated with decreased fertility, decreased E2 concentrations before AI, and decreased P4 concentrations after AI (Vasconcelos et al., 2001). The superior reproductive performance observed by Herlihy et al. (2011) with CIDR_OBS may be partly explained by the findings of the present study, which suggest that treatment of animals with CIDR_OBS resulted in increased preovulatory follicle diameter.

After P4 withdrawal, an increase in LH pulse frequency and mean LH concentrations promote follicle growth and increased E2 production. Following CIDR removal, circulating E2 concentrations increased rapidly for CIDR_OBS and CIDR_TAI. Although the onset of proestrus (i.e., the interval from luteal regression to the LH surge) was delayed by $24 \mathrm{~h}$ for animals treated with CIDR_OBS and CIDR_TAI, proestrus concentrations of E2 were greater for CIDR_OBS compared with Ovsynch. At $60 \mathrm{~h}$ after PGF injection circulating concentrations of E2 remained greater for CIDR_OBS compared with Ovsynch. With TAI treatments, GnRH2 is given to precisely control the timing of ovulation. In the current study, GnRH2 caused a rapid decrease in circulating E2 concentrations in both TAI treatments. Consequently, Ovsynch had lesser peak preovulatory E2 and both CIDR_TAI and Ovsynch had peak preovulatory E2 earlier compared with CIDR_OBS. Typically, during TAI treatments, GnRH2 induces an endogenous LH surge before circulating E2 concentrations have reached peak concentrations, as evidenced by a lack of estrous behavior in most cows treated with Ovsynch (Souza et al., 2007). Greater preovulatory E2 concentrations have been linked to improved likelihood of successful pregnancy establishment (Lopes et al., 2007). The greater conception rates reported by Herlihy et al. (2011) for CIDR-based treatments may be at least partially attributable to higher periovulatory concentrations of E2. Hawk (1983) reported that reductions in periovulatory E2 concentrations might compromise spermatozoa transport in the female reproductive tract, and give rise to a suboptimal oviductal/uterine environment, and impaired oocyte fertilization.

In agreement with previous findings (Vasconcelos et al., 2001; Lopes et al., 2007), the present study demonstrated that peak circulating concentrations of E2 and 
preovulatory dominant follicle diameter were positively associated. Cumulative milk yield from wk 2 to 5 of lactation was negatively associated with preovulatory follicle diameter in the present study. This is in contrast to Lopez et al. (2004), who reported that milk production was positively correlated with preovulatory follicle diameter. Those authors also reported that milk production was negatively correlated with circulating concentrations of E2. Lower circulating E2 concentration was suggested as a reason for the greater preovulatory follicle size by delaying the time to the estradiolinduced LH surge and ovulation (Lopez et al., 2004). In the current study, DIM at the start of synchronization treatment was positively associated with peak circulating concentrations of E2. This reflects improved follicle steroidogenic capacity with increasing postpartum interval, likely due to increased LH pulse frequency associated with improved energy status (Canfield and Butler, 1990).

Treatments to synchronize ovulation allow the time of AI to be optimized, whereas increased variability in the timing of ovulation is observed when treatments to synchronize estrus are used. A decrease in pregnancy rate occurs as the duration of preovulatory follicle dominance increases (Mihm et al., 1994; Austin et al., 1999). Prolonged dominance of the ovulatory follicle decreases embryo quality both in cows submitted to TAI treatments (Cerri et al., 2009) and cows inseminated following spontaneous estrus (Bleach et al., 2004). Saumande and Humblot (2005) reported that 80.6\% of the variation in the interval between the onset of estrus and ovulation is explained by variation in the interval between the onset of estrus and the occurrence of the LH surge. Animals treated with CIDR_TAI and Ovsynch were administered $\mathrm{GnRH}$, which resulted in a narrow range in time to ovulation whereby all animals had ovulated by $96 \mathrm{~h}$ following PGF injection. In contrast, more variability was observed in the interval from PGF injection to ovulation for animals treated with CIDR_OBS, as these animals relied on an endogenous LH surge. Despite greater variation in the interval from PGF injection to ovulation observed with CIDR_OBS, the incidence of prolonged dominance of the ovulatory follicle was low (i.e., 1 animal with an interval from PGF injection to ovulation $>116$ h). Furthermore, based on the fertility performance reported by Herlihy et al. (2011) using similar treatments, it is unlikely that prolonged dominance is prevalent in Irish dairy cattle treated with CIDR_OBS. Larger preovulatory follicle size and greater circulating concentrations of E2 were due to a longer period of preovulatory follicle growth, but no evidence was found that animals treated with CIDR_OBS developed persistent follicles.
The later occurrence of ovulation for CIDR_OBS compared with CIDR_TAI suggests that the timing of GnRH2 may have been suboptimal for animals treated with CIDR_TAI. Where GnRH2 was not administered (i.e., CIDR_OBS) the duration of proestrus was increased and greater periovulatory concentrations of E2 were observed. Thus, we hypothesize that a modest increase in the interval between CIDR removal and GnRH2 may be beneficial for preovulatory follicle growth and E2 production.

In the present study, differences between treatments in ovulatory follicle size, and periovulatory circulating concentrations of P4 and E2 were observed. Despite this, no treatment differences in postovulatory $\mathrm{P} 4$ concentrations or luteal volume were observed. This is perhaps surprising, and was not consistent with Vasconcelos et al. (2001), who suggested that decreasing the size of the ovulatory follicle had a negative effect on fertility due to development of smaller corpora lutea, giving rise to lesser $\mathrm{P} 4$ concentrations. Importantly, the size of the ovulatory follicle reported by Vasconcelos et al. (2001) was smaller than size of the ovulatory follicle reported in the present study. Although the timing of GnRH2 for CIDR_TAI may have been suboptimal for final follicle development, the results suggest no adverse effects on subsequent CL development or steroidogenic capacity of the CL.

\section{CONCLUSIONS}

This study has demonstrated differences in periovulatory E2 concentrations between treatments to synchronize estrus and ovulation. Increased periovulatory E2 concentrations were observed for CIDR_OBS compared with Ovsynch. Administration of GnRH2 caused an abrupt decrease in circulating E2 concentrations and resulted in a narrow range in time to ovulation for CIDR_TAI and Ovsynch. In contrast, a larger variation in the time of ovulation was observed for CIDR_OBS due to variation in time to estrus and the LH surge. Although differences between treatments in ovulatory follicle size, and periovulatory P4 and E2 concentrations were observed, no differences in postovulatory $\mathrm{P} 4$ or luteal volume profiles were observed.

\section{ACKNOWLEDGMENTS}

The authors thank John Paul Murphy (Teagasc, Moorepark, County Cork, Ireland) and the Moorepark farm staff for management and care of the animals. Technical support was provided by Jonathon Kenneally (Teagasc Moorepark), Assumpta Glynn (Teagasc Athenry), and Niamh Hynes (University College Dub- 
lin, Ireland). This study was funded by the National Development Plan and the Dairy Levy Trust Fund.

\section{REFERENCES}

Ahmad, N., F. N. Schrick, R. L. Butcher, and E. K. Inskeep. 1995. Effect of persistent follicles on early embryonic losses in beef cows. Biol. Reprod. 52:1129-1135.

Allrich, R. D. 1994. Endocrine and neural control of estrus in dairy cows. J. Dairy Sci. 77:2738-2744.

Austin, E. J., M. Mihm, M. P. Ryan, D. H. Williams, and J. F. Roche. 1999. Effect of duration of dominance of the ovulatory follicle on onset of estrus and fertility in heifers. J. Anim. Sci. 77:2219-2226.

Bamber, R. L., G. E. Shook, M. C. Wiltbank, J. E. Santos, and P. M. Fricke. 2009. Genetic parameters for anovulation and pregnancy loss in dairy cattle. J. Dairy Sci. 92:5739-5753.

Bello, N. M., J. P. Steibel, and J. R. Pursley. 2006. Optimizing ovulation to first GnRH improved outcomes to each hormonal injection of Ovsynch in lactating dairy cows. J. Dairy Sci. 89:3413-3424.

Bleach, E. C., R. G. Glencross, and P. G. Knight. 2004. Association between ovarian follicle development and pregnancy rates in dairy cows undergoing spontaneous oestrous cycles. Reproduction 127:621-629.

Brusveen, D. J., A. P. Cunha, C. D. Silva, P. M. Cunha, R. A. Sterry, E. P. B. Silva, J. N. Guenther, and M. C. Wiltbank. 2008. Altering the time of the second gonadotropin-releasing hormone injection and artificial insemination (AI) during Ovsynch affects pregnancies per AI in lactating dairy cows. J. Dairy Sci. 91:1044-1052.

Canfield, R. W., and W. R. Butler. 1990. Energy balance and pulsatile LH secretion in early postpartum dairy cattle. Domest. Anim. Endocrinol. 7:323-330.

Cerri, R. L., H. M. Rutigliano, R. C. Chebel, and J. E. Santos. 2009. Period of dominance of the ovulatory follicle influences embryo quality in lactating dairy cows. Reproduction 137:813-823.

Clemente, M., J. de La Fuente, T. Fair, A. Al Naib, A. Gutierrez-Adan, J. F. Roche, D. Rizos, and P. Lonergan. 2009. Progesterone and conceptus elongation in cattle: A direct effect on the embryo or an indirect effect via the endometrium? Reproduction 138:507-517.

Edmonson, A. J., I. J. Lean, L. D. Weaver, T. Farver, and G. Webster. 1989. A body condition scoring chart for Holstein dairy cows. J. Dairy Sci. 72:68-78.

Forde, N., M. E. Beltman, G. B. Duffy, P. Duffy, J. P. Mehta, P. O'Gaora, J. F. Roche, P. Lonergan, and M. A. Crowe. 2011. Changes in the endometrial transcriptome during the bovine estrous cycle: Effect of low circulating progesterone and consequences for conceptus elongation. Biol. Reprod. 84:266-278.

Gazal, O. S., L. S. Leshin, R. L. Stanko, M. G. Thomas, D. H. Keisler, L. L. Anderson, and G. L. Williams. 1998. Gonadotropin-releasing hormone secretion into third-ventricle cerebrospinal fluid of cattle: Correspondence with the tonic and surge release of luteinizing hormone and its tonic inhibition by suckling and neuropeptide Y. Biol. Reprod. 59:676-683.

Gümen, A., J. N. Guenther, and M. C. Wiltbank. 2003. Follicular size and response to Ovsynch versus detection of estrus in anovular and ovular lactating dairy cows. J. Dairy Sci. 86:3184-3194.

Haughian, J. M., O. J. Ginther, K. Kot, and M. C. Wiltbank. 2004. Relationships between FSH patterns and follicular dynamics and the temporal associations among hormones in natural and $\mathrm{GnRH}-$ induced gonadotropin surges in heifers. Reproduction 127:23-33.

Hawk, H. W. 1983. Sperm survival and transport in the female reproductive tract. J. Dairy Sci. 66:2645-2660.

Herlihy, M. M., D. P. Berry, M. A. Crowe, M. G. Diskin, and S. T. Butler. 2011. Evaluation of protocols to synchronize estrus and ovulation in seasonal calving pasture-based dairy production systems. J. Dairy Sci. 94:4488-4501.

Komar, C. M., A. K. Berndtson, A. C. Evans, and J. E. Fortune. 2001. Decline in circulating estradiol during the periovulatory period is correlated with decreases in estradiol and androgen, and in messenger RNA for p450 aromatase and p450 17 $\alpha$-hydroxylase, in bovine preovulatory follicles. Biol. Reprod. 64:1797-1805.
Lopes, A. S., S. T. Butler, R. O. Gilbert, and W. R. Butler. 2007. Relationship of pre-ovulatory follicle size, estradiol concentrations and season to pregnancy outcome in dairy cows. Anim. Reprod. Sci. 99:34-43.

Lopez, H., L. D. Satter, and M. C. Wiltbank. 2004. Relationship between level of milk production and estrous behavior of lactating dairy cows. Anim. Reprod. Sci. 81:209-223.

Mee, J. F., F. Buckley, D. Ryan, and P. Dillon. 2009. Pre-breeding ovaro-uterine ultrasonography and its relationship with first service pregnancy rate in seasonal-calving dairy herds. Reprod. Domest. Anim. 44:331-337.

Mihm, M., A. Baguisi, M. P. Boland, and J. F. Roche. 1994. Association between the duration of dominance of the ovulatory follicle and pregnancy rate in beef heifers. J. Reprod. Fertil. 102:123-130.

Morris, D., and M. Diskin. 2008. Effect of progesterone on embryo survival. Animal 2:1112-1119.

Nebel, R. L., W. L. Walker, M. L. McGilliard, C. H. Allen, and G. S. Heckman. 1994. Timing of artificial insemination of dairy cows: Fixed time once daily versus morning and afternoon. J. Dairy Sci. 77:3185-3191.

Prendiville, D. J., W. J. Enright, M. A. Crowe, M. Finnerty, N. Hynes, and J. F. Roche. 1995. Immunization of heifers against gonadotropin-releasing hormone: Antibody titers, ovarian function, body growth, and carcass characteristics. J. Anim. Sci. 73:2382-2389.

Pursley, J. R., M. O. Mee, and M. C. Wiltbank. 1995. Synchronization of ovulation in dairy cows using $\mathrm{PGF}_{2 \alpha}$ and GnRH. Theriogenology 44:915-923.

Pursley, J. R., R. W. Silcox, and M. C. Wiltbank. 1998. Effect of time of artificial insemination on pregnancy rates, calving rates, pregnancy loss, and gender ratio after synchronization of ovulation in lactating dairy cows. J. Dairy Sci. 81:2139-2144.

Revah, I., and W. R. Butler. 1996. Prolonged dominance of follicles and reduced viability of bovine oocytes. J. Reprod. Fertil. 106:39-47.

Sartori, R., P. M. Fricke, J. C. Ferreira, O. J. Ginther, and M. C. Wiltbank. 2001. Follicular deviation and acquisition of ovulatory capacity in bovine follicles. Biol. Reprod. 65:1403-1409.

SAS Institute. 2006. SAS User's Guide: Statistics. SAS Inst. Inc., Cary, NC.

Saumande, J., and P. Humblot. 2005. The variability in the interval between estrus and ovulation in cattle and its determinants. Anim. Reprod. Sci. 85:171-182.

Souza, A. H., A. Gümen, E. P. Silva, A. P. Cunha, J. N. Guenther, C. M. Peto, D. Z. Caraviello, and M. C. Wiltbank. 2007. Supplementation with estradiol-17 $\beta$ before the last gonadotropin-releasing hormone injection of the Ovsynch protocol in lactating dairy cows. J. Dairy Sci. 90:4623-4634.

Spencer, T. E., R. C. Burghardt, G. A. Johnson, and F. W. Bazer. 2004. Conceptus signals for establishment and maintenance of pregnancy. Anim. Reprod. Sci. 82-83:537-550.

Stevenson, J. S., D. E. Tenhouse, R. L. Krisher, G. C. Lamb, J. E. Larson, C. R. Dahlen, J. R. Pursley, N. M. Bello, P. M. Fricke, M. C. Wiltbank, D. J. Brusveen, M. Burkhart, R. S. Youngquist, and H. A. Garverick. 2008. Detection of anovulation by heatmount detectors and transrectal ultrasonography before treatment with progesterone in a timed insemination protocol. J. Dairy Sci. 91:2901-2915.

Thatcher, W. W., J. E. P. Santos, F. T. Silvestre, I. H. Kim, and C. R. Staples. 2010. Perspective on physiological/endocrine and nutritional factors influencing fertility in post-partum dairy cows. Reprod. Domest. Anim. 45:2-14.

Vasconcelos, J. L. M., R. Sartori, H. N. Oliveira, J. G. Guenther, and M. C. Wiltbank. 2001. Reduction in size of the ovulatory follicle reduces subsequent luteal size and pregnancy rate. Theriogenology 56:307-314.

Vasconcelos, J. L. M., R. W. Silcox, G. J. M. Rosa, J. R. Pursley, and M. C. Wiltbank. 1999. Synchronization rate, size of the ovulatory follicle, and pregnancy rate after synchronization of ovulation beginning on different days of the estrous cycle in lactating dairy cows. Theriogenology 52:1067-1078. 